\title{
Antibacterial Property of Extract of Erveniastrum nepalense (Edible Lichen) Collected from Hilly Regions of Eastern Nepal
}

\author{
Saraswati Yonghang ${ }^{1}$, Suman Rai ${ }^{1}$, Shiv Nandan Sah ${ }^{1}$ \\ ${ }^{1}$ Department of Microbiology, Central Campus of Technology, Tribhuvan University, Dharan, Sunsari, Nepal
}

*Corresponding author: Shiv Nandan Sah, Department of Microbiology, Central Campus of Technology, Tribhuvan University, Dharan, Sunsari, Nepal; Email:sahshivnandan96@gmail.com

ABSTRACT

Objectives: To evaluate the antibacterial property of Everniastrum nepalense(edible lichen)collected from eastern part of Nepal and determine Minimum Inhibitory Concentration (MIC) of lichen extract.

Methods: Everniastrum nepalense was collected from local Rai and Limbu community in a plastic bag from four hilly districts (Pachthar, Taplejung, Dhankuta and Bhojpur) of Eastern, NepaMoisture content in lichen samples were removed by air drying and grinded to powdery form. The methanolic extracts of lichens of different places were prepared by solvent extraction process using Soxhlet apparatus and tested against human pathogenic bacteria by disc diffusion method. Then, Minimum Inhibitory Concentration (MIC) of lichen extracts was determined using well diffusion method.

Results: The lichens extract against the test bacterial isolates were performed by agar well diffusion method. Overall, it was observed that all these lichen extracts from Eastern Nepal had inhibitory effect on both Gram-positive and Gram-negative bacteria. Out of seven bacterial samples used, all bacterial samples were inhibited by the lichen extracts except Escherichia coli. The effect of lichen extract collected from Bhojpur district had maximum zone of inhibition against Staphylococcus aureus, Salmonella Typhi and Klebsiella spp were found to be $13 \mathrm{~mm}, 14 \mathrm{~mm}$ and $14 \mathrm{~mm}$ respectively. Similarly, zone of inhibition against Bacillus subtilis was found to be $17 \mathrm{~mm}$ from samples of Dhankuta, which was highest value than other 3 districts viz; Bhojpur, Taplejung and Pachthar District. Likewise, Pseudomonas aeruginosa showed highest inhibition value i.e. $18 \mathrm{~mm}$ on Pachthar sample whereas, Shigella showed $15 \mathrm{~mm}$ on Dhankuta sample. This study revealed that inhibitory capacity of edible lichen (Everniastrum nepalense) against test bacteria was not the same. It varied from place to place.

Conclusion: This study has concluded that Everniastrum nepalensehas potential antibacterial property against Bacillus subtilis, Staphylococcus aureus, Escherichia coli, Salmonella spp, Shigella spp, Klebsiella spp and Pseudomonas aeruginosa except E. coli along with nutritional value and can be used as safe alternative and economic herbal medicine to treat infectious diseases.

Key words: Lichen extracts, antimicrobial activity, zone of inhibition, Minimum Inhibitory Concentration.

\section{INTRODUCTION}

Lichens are being used in traditional foods and medicines since millenia and also play vital roles in ecosystem function and human welfare (Crawford 2015). According to WHO, approximately $80 \%$ of present world's people depend on traditional medicine for primary health cares. Indigenous traditional medicine has considerable economic benefits as well as it can be used in the treatment of various diseases (Azaizeh et al. 2003).

Date of Submission: August 25, 2019

Published Online: December, 2019
According to Crockett et al. (2003), Lichens are the symbiotic association between two organisms (Fungi and its photosynthetic partner algae) which live together intimately.The fungus forms a thallus or lichenized stroma that may contain characteristic secondary metabolites in all lichens (Ahmadijan 1993). Lichens, frequently called 'Jhyau' or 'Tare' in Nepal, are classified as a cluster of lower life-forms of fungi (Shah 2014). Although about $8 \%$ of the terrestrial ecosystem consists of lichens and more than 20,000 lichen species

Date of Acceptance: December 2, 2019

DOI: https:/ / doi.org/10.3126/tujm.v6i0.26584 
are distributed throughout the world, their biological activities and biologically active compounds remain unexplored to a great extent (Toma et al. 2001).

Lichens are considered as valuable plant resources which are used as medicines, food, fodder, dyes perfume, spice, and for miscellaneous purposes (Hegnauer 1962). Lichens are also used for monitoring the air pollution because they are very sensitive to various air pollutants (Jezierski et al. 1999).

The use of lichens in medicine is based on the fact that they contain unique and varied biologically active substances, mainly with antimicrobial actions. Because of marked antimicrobial activity of secondary metabolites, lichens, macrofungi, and vascular plants attract great attention of investigators as new significant sources of bioactive substances (Karaman et al. 2003). The intensive use of antibiotics has selected for antibiotic resistance factors and facilitated the spread of multiply resistant microorganisms.

Lichen metabolites constitute a wide variety of biological function including antibiotic, antimycotic, antiviral, anti-inflammatory, analgesic, antipyretic, antiproliferative, and cytotoxic effects (Shukla et al. 2010; Manojlovic et al. 2010).

Various lichens and its extracts having usnic acid have been used for medicinal, perfumery, cosmetic as well as ecological purposes. In some commercial products such as creams, toothpaste, mouthwash, deodorants and sunscreen products, usnic acid has been formulated as a pure substance as well as in some cases used as an active principle, in others as a preservative. In addition to the antimicrobial activity against human and plant pathogens, usnic acid has been shown to exhibit antiviral, antiprotozoal, antiproliferative, antiinflammatory and analgesic activities (Ingolfsdottir 2002). Slow growth and long duration (maximum lifetime spans to several thousand years) of existence in the specific and even extreme conditions are consistent with their abundance in protective metabolites against different physical and biological influences (Denton and Karlen 1973). Ecological effects, such as antigrowth, antiherbivore and anti-insect properties of lichens have also been reported (Ingolfsdottir 2002). Edible lichen (Everniastrum cirrhatum, E. nepalense and Parmotrema cetratum) is also supposed to be effective in healing various diseases. Several lichen species have been used in folk medicine for treatment of stomach diseases, diabetes, whooping, cough, pulmonary tuberculosis, cancer, skin diseases. Lichen extracts can inhibit Bacillus subtilis which mainly causes nausea and diarrhea. So, it is good treatment for such a problem. Recently, many plants have received attention as sources of antibiotics (Basile et al. 2000).

Several ethnomedicinal plants of Nepal have been identified and their usage documented. These documented plants have been used as antibacterial, antifungal, antiviral and for other general treatments (Rudrappa and Bais 2008).

Three of the selected medicinal plants (O. sanctum, Z. alatum and C. tamala) were successful in exhibiting antibacterial effect against common MDR Gram negative isolates (Thapa et al., 2018)

The potential bioactive compound of natural plant extracts that are economical. Among seven extracts examined Snyzygium aromaticum, Pisidium guajava and Elaeocarpus ganitrus showed the best antibacterial activity against S. aureus (Sakha et al. 2018).

In this regard, edible lichen from Eastern part of Nepal is of a significant interest. Therefore, in this study, antibacterial activity and MIC of methanolic extracts of Erveniastrum nepalense were evaluated against human pathogenic bacteria. This study was designed to contribute scientific proof for utilization of locally available edible lichen as herbal medicine in comparison to the commercial antibiotics having various side effects.

\section{MATERIALS AND METHODS}

\section{Collection of lichen samples}

Everniastrum nepalense was collected in a plastic bag from various areas of Pachthar, Taplejung, Dhankuta and Bhojpur districts of Eastern Nepal in May 2018 and this study was carried out up to July 2018 months in the microbiology laboratory of Central Campus of Technology, Hattisar, Dharan.

Test bacteria such as Bacillus subtilis, Staphylococcus aureus, Escherichia coli, Salmonella spp, Shigella spp, Klebsiella spp and Pseudomonas aeruginosa obtained from the Department of Microbiology, Central Campus of Technology, Dharan, were used for study of antimicrobial activity of lichen extracts.

\section{Preparation of extracts}

Ten gram (10 g) of collected sample of Everniastrum nepalense was weighed and placed in individual thimble and enclosed in it. After enclosing the sample, 
Methanol was taken as a solvent. Each thimble with sample was placed on individual Soxhlet apparatus for solvent extraction. The solvents were left to siphoned single time. Then again, the solvent was added, so as to cover thimble. The temperature was adjusted at around $55-60^{\circ} \mathrm{C}$, where the boiling point of methanol is $64.7^{\circ} \mathrm{C}$. The process of siphoning was started and done until the extraction becomes transparent. The extracts were poured on a beaker and concentrated to dryness using rotary evaporator. This process was repeated when more lichen extract was required. The extracts were then ready for testing antimicrobial activity (Jasuja et al. 2013).

\section{Preparation of standard inoculums of test bacteria}

The antibacterial activity of Everniastrum nepalense extract was tested against test bacteria such as Bacillus subtilis, Staphylococcus aureus, Escherichia coli, Salmonella spp., Shigella spp., Klebsiella spp. and Pseudomonas aeruginosa.

For this, 0.5 McFarland standard inoculums from pure culture of test bacteria were prepared in a separate test tube containing nutrient broth at $37^{\circ} \mathrm{C}$ and were maintained.

\section{Evaluation of antibacterial activity}

The antibacterial activity was screened by both agar well diffusion (Basri and Nor 2014) on Mueller-Hinton agar (MHA) against test bacteria. The $20 \mathrm{ml}$ of sterilized Muller Hinton Agar was poured into sterile petri plates, after solidification, $100 \mu \mathrm{l}$ of fresh culture of Test bacteria (0.5 Mc-Farland standards) were uniformly swabbed on the respective plates. The wells of $6 \mathrm{~mm}$ diameter were bored in the inoculated plates using sterile cork borer and the lichen extracts of $100 \mathrm{ml}$ were loaded into respective well and incubated at $37^{\circ} \mathrm{C}$ for 24 hours. After incubation the diameter of inhibitory zones formed around the well were measured.

\section{Minimum Inhibitory Concentration}

MIC was determined using well diffusion method. The prepared MHA plates were inoculated with respective test bacteria, (Staphylococcus aureus, Bacillus subtilis, Pseudomonas aeruginosa, Escherichia coli, Shigella spp., Klebsiella spp. and Salmonella Typhi).

Standardization of bacterial suspension: McFarland standard was used as a reference to adjust turbidity of bacterial sample. Bacterial suspension was grown in Nutrient broth for 18-24h, followed by the matching of bacterial suspension to the turbidity equivalent to 0.5
McFarland solutions.

Determination of MIC: The prepared MHA plates were inoculated with respective test organisms, i.e. Staphylococcus aureus, Bacillus subtilis, Pseudomonas aeruginosa, Escherichia coli, Shigella spp., Klebsiella spp. and Salmonella Typhi.

Seven wells of $6 \mathrm{~mm}$ diameter were made at least $1.5 \mathrm{~mm}$ edge of the plate. Each well was labeled for the amount of extract to keep on. Various lichen extracts of $100 \mathrm{mg} /$ $\mathrm{mL}, 50 \mathrm{mg} / \mathrm{mL}, 25 \mathrm{mg} / \mathrm{mL}, 12.5 \mathrm{mg} / \mathrm{mL}, 6.25 \mathrm{mg} / \mathrm{mL}$ and $3.125 \mathrm{mg} / \mathrm{mL}$ of extract were respectively poured in six wells and dimethyl sulphoxide (DMSO) solution as a control was poured in remaining one well. Whole system were kept undisturbed and allowed to dry for few minutes. The plates were inoculated at $37^{\circ} \mathrm{C}$ for 24 hours for the determination of minimum inhibitory concentration. The concentrations were made by mixing DMSO with crude solid extracts. The MIC was interpreted as the lowest concentration of the extract that showed visible zone of inhibition when compared to control plate well that contained only the DMSO.

\section{RESULTS}

In this study, methanolic extracts of edible lichen collected from four different places namely Bhojpur, Dhankuta, Panchthar and Taplejung were evaluated for their antibacterial activity against human pathogenic bacteria such as ATCC strain of Bacillus subtilis, Staphylococcus aureus, Escherichia coli, Salmonella spp., Shigella spp., Klebsiella spp. and Pseudomonas aeruginosa by agar well assay method.

Overall, it was observed that all these lichen extracts from Eastern part of Nepal had inhibitory effect on both Gram-positive and Gram-negative bacteria. Out of seven test bacteria, all were inhibited by the lichen extracts except Gram-negative Escherichia coli (Table 1).

The effect of extract of lichen collected from Bhojpur district showed that the maximum zone of inhibition against Staphylococcus aureus, Salmonella Typhi and Klebsiella spp., were found to be $13 \mathrm{~mm}, 14 \mathrm{~mm}$ and 14 $\mathrm{mm}$ respectively. Similarly, that of Dhankuta district against Bacillus subtilis was found to be $17 \mathrm{~mm}$, which was highest value than other 3 districts viz; Bhojpur, Taplejung and Pachthar districts. Similarly, extract of Dhankuta sample showed highest inhibition values (15 mm) against Shigella spp., whereas extract of Pachthar sampleshowed highest inhibition values (18 $\mathrm{mm})$ against Pseudomonas aeruginosa. Hence, all the 
Yonghang et al. 2019, TUJM 6(1): 51-58

bacterial species except Escherichia coli were inhibited by different lichen extracts.

Table 1: Effect of extracts on test bacteria on well diffusion

\begin{tabular}{lcccc}
\hline \multirow{2}{*}{ Organisms } & \multicolumn{4}{c}{ Zone of inhibition $(\mathrm{mm})$ using lichen extract of } \\
\cline { 2 - 5 } & Bhojpur & Dhankuta & Panchthar & Taplejung \\
\hline E. coli & - & - & - & - \\
S. aureus & 13 & 12 & 12 & 12 \\
S. Typhi & 14 & 13 & 11 & 12 \\
B. subtilis & 14 & 17 & 16 & 12 \\
P. aeruginosa & 10 & 14 & 18 & 15 \\
Klebsiella spp & 14 & 10 & 10 & 13 \\
Shigella spp & 12 & 15 & 12 & 11 \\
\hline
\end{tabular}

Table 2: Zone of inhibition of test bacteria for MIC determination

\begin{tabular}{lcccc}
\hline \multirow{2}{*}{ Organisms } & \multicolumn{4}{c}{ MIC $(\mathrm{mg} / \mathrm{mL})$ value of lichen collected from } \\
\cline { 2 - 5 } & Bhojpur & Dhankuta & Panchthar & Taplejung \\
\hline E.coli & - & - & - & - \\
S. aureus & 12.5 & 25 & 6.25 & 25 \\
S. Typhi & 25 & 6.25 & 6.25 & 50 \\
B. subtilis & 6.25 & 6.25 & 6.25 & 6.25 \\
P. aeruginosa & 25 & 6.25 & 6.25 & 6.25 \\
Klebsiella spp & 6.25 & 25 & 50 & 50 \\
Shigella spp & 25 & 6.25 & 50 & 50 \\
\hline
\end{tabular}

All Lichen extracts showed no any antibacterial activity against Escherichia coli. Hence, it is concluded that there was no effect on growth of $E$. coli. MIC values of the lichen extracts of Taplejung and Dhankuta against Staphylococcus aureus were same $(25 \mathrm{mg} / \mathrm{mL})$ whereas that of Bhojpur and Pachthar was found to be $12.5 \mathrm{mg} / \mathrm{mL}$ and $6.25 \mathrm{mg} / \mathrm{mL}$ respectively (Table 2 ).

MIC values of the lichen extracts of Bhojpur, Dhankuta, Pachthar and Taplejung against Salmonella Typhi were $25 \mathrm{mg} / \mathrm{mL}, 6.25 \mathrm{mg} / \mathrm{mL}, 6.25 \mathrm{mg} / \mathrm{mL}$ and $50 \mathrm{mg} / \mathrm{mL}$ respectively. Similarly, MIC value of the lichen extracts of all four districts against Bacillus

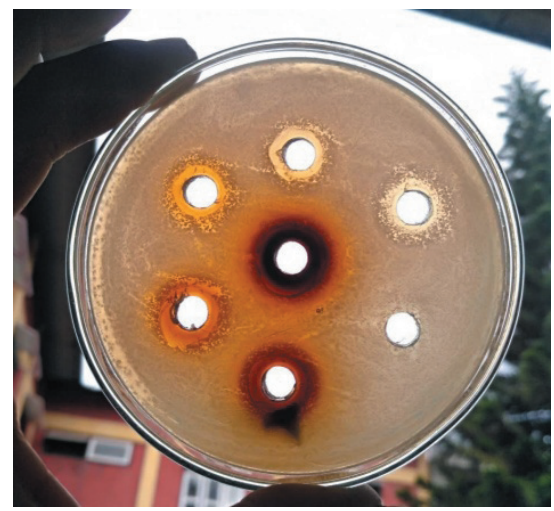

Photograph 1: Zone of inhibition against Bacillus subtilis by Bhojpur sample subtilis were same i.e. $6.25 \mathrm{mg} / \mathrm{mL}$. Hence, B. subtilis was equally affected by lichens extracts. Likewise, MIC value of the lichen extracts of Bhojpur against Pseudomonas aeruginosa was found to be $25 \mathrm{mg} / \mathrm{mL}$ whereas $6.25 \mathrm{mg} / \mathrm{mL}$ on all remaining three lichens extracts from remaining three districts. On other hand, Klebsiella and Shigella have same value of MIC with Pachthar and Taplejung lichen extracts i.e. 50 $\mathrm{mg} / \mathrm{mL}$ whereas, their value differs within Bhojpur and Dhankuta lichen extracts viz; $6.25 \mathrm{mg} / \mathrm{mL}, 25$ $\mathrm{mg} / \mathrm{mL}$ and $25 \mathrm{mg} / \mathrm{mL}, 6.25 \mathrm{mg} / \mathrm{mL}$ on Bhojpur and Dhankuta samples respectively.

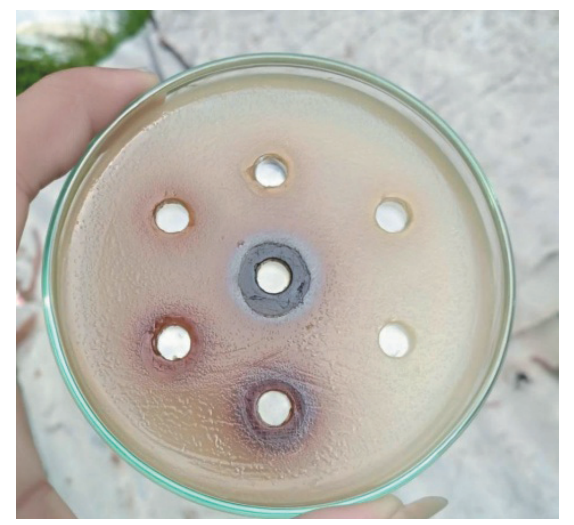

Photograph 2: Zone of inhibition against Shigella spp by Taplejung sample 


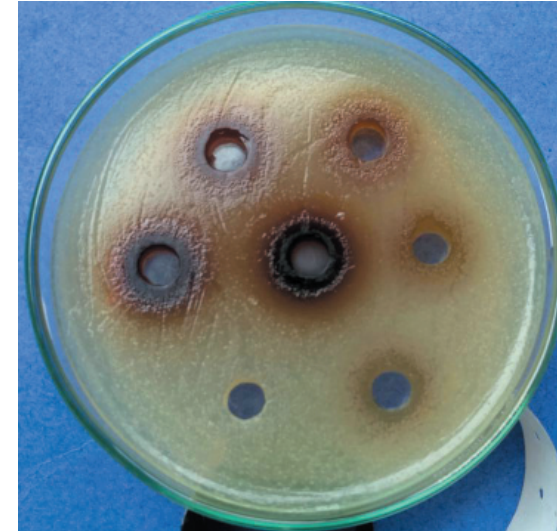

Photograph 3: Zone of inhibition against Staphylococcus aureus by Pachthar sample

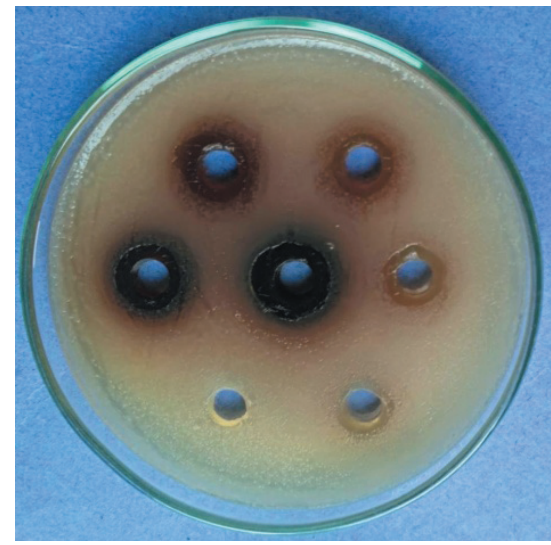

Photograph 5: Zone of inhibition against Salmonella Typhi by Dhankuta sample

So, it was concluded that lichen sample from Pachthar was more effective against Staphylococcus aureus. Samples from Dhankuta and Pachthar were equally effective against $S$. Typhi than other two samples.So, it is concluded that $P$. aeruginosa was less affected by Bhojpur sample while both Shigella spp and Klebsiella spp showed most resistance against the lichen extracts of Pachthar and Taplejung samples. Therefore, MIC value of the lichen extracts of Bhojpur against Klebsiella spp. was found to be effective and that of lichen extracts of Dhankuta was effective against Shigella spp. Overall it is concluded that the lichen extracts from lichens of Dhankuta was the most effective against test bacteria being used except Escherichia coli. DMSO solution is used as a control for each system.

\section{DISCUSSION}

Plant product drugs and herbal remedies have been employed since prehistoric times to treat human and animal diseases and several countries still rely on plants

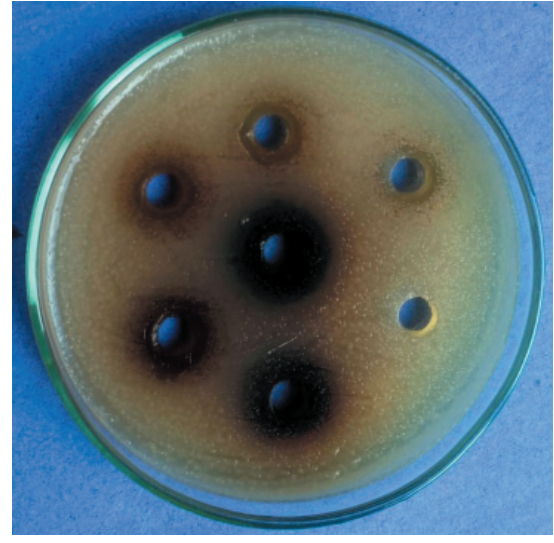

Photograph 4: Zone of inhibition against

Pseudomonas aeruginosa by Dhankuta sample

and herbs as the main sources of drugs (Ogbonnia et al. 2008).

Lichens, the symbiotic organisms of fungi and algae, are slow-growing organisms (Fiedler et al., 1986). Their secondary metabolites as the "lichen substances," are amino acid derivatives, sugar alcohols, aliphatic acids, macrocyclic lactones, mono-cyclic aromatic compounds, quinones, chromones, xanthones, dibenzofuranes, depsides, depsidones, depsones, terpenoids, steroids, carotenoids and diphenyl ethers. They have been used by humans for centuries as food, dye and therapeutic traditional medicine. Their efficacy is due to the synthesis of unique secondary compounds, a number of which have important biological roles (Perry et al. 1999).

For this study, edible lichen (Everniastrum nepalense) was collected from four different districts of eastern Nepal viz. Bhojpur, Dhankuta, Panchthar and Taplejung.

Lichens are used as medicinal plants as well as food commodities by the some ethnic groups especially Rai and Limbu from Kirat community of Eastern Nepal. (Limbu 2013).

The edible lichens such as Everniastrum cirrhatum, E. nepalense and Parmotrema cetratum are are famous for its delicacy and high nutritional values and hence are widely eaten along with cooked blood, intestinal parts of pigs with spices and seasonings by the Limbu and Rai communities (Limbu and Rai 2012; Limbu 2013).

Extracts were evaluated for their antibacterial activity against human pathogenic bacteria such as Bacillus subtilis, Staphylococcus aureus, Escherichia coli, Salmonella spp., Shigella spp., Klebsiella spp. and Pseudomonas aeruginosa by agar well assay method. 
The extracts of all edible lichens showed inhibitory effects against all test bacteria except Escherichia coli. This study is similar to the result obtained by Dulger et al. (1998).The species of the edible lichens including Everniastrum cirrhatum, E. nepalense and Parmotrema cetratum shown to exhibit inhibitory effect against bacteria including clinical isolates (Limbu and Rai 2012). The lichen extracts containing bio-active compounds showed inhibitory activity against wide variety of human pathogens including clinical strains (Kosanić et al. 2014).

Inhibitory Zone shown by methanol extracts of Lichen collected from four different districts varied according to bacteria used. Range of zone of inhibition obtained as results was 10 to $18 \mathrm{~mm}$ against test bacteria. The intensity of the antimicrobial effect depended on the type of extract, its concentration, and the tested microorganisms (Srivastava et al. 2013).Acetone and methanol extract showed almost equal activity against $S$. aureus whereas ethanol extract was found to be more effective against $B$. cereus and $P$. aeruginosa. The reason for different sensitivity of bacteria can be found in different transparency of the cell wall (Yang and Anderson 1999).

From the result obtained, it is concluded that lichen extracts showed less antibacterial activity on Gramnegative bacteria as compared to Gram-positive bacteria which is matched with that of Lawrey (1986). This can be justified with reference to Lodhia et al. (2009) and Nalubega et al. (2011) because the lesser inhibitory activity of solvent extracts against the Gram negative bacterium could be described to the presence of an outer membrane that possess hydrophilic polysaccharides chains and forms an additional barrier for extracts as well as antibiotics whereas the cell wall of the Gram-positive bacteria consists of peptidoglycan (mureins) and teichoic acids.

Behera et al. (2005) reported that the acetone, methanol, and light petroleum extracts of lichen were effective against Bacillus licheniformis, B. megaterium, and $S$. aureus. Karagoz et al. (2009) reported antibacterial activity of aqueous and ethanolic extracts lichens like Lecanora muralis, Peltigerapolydactyla, Ramalina farinacea, and Xanthoria elegans.

Everniastrum nepalense showed that MIC values were varying between $6.5 \mathrm{mg} / \mathrm{mLand} 50 \mathrm{mg} / \mathrm{mL}$. Minimum inhibitory concentrations (MICs) was used to characterize the biological activity of various lichen solvent extracts.
In this study it was obtained that Dhankuta sample was the most effective against all test bacteria except Escherichia coli. Similarly, Panchhar and Bhojpur samples were ranked as second and third antimicrobial effective samples respectively. Taplejung sample was considered as a sample having least antimicrobial activity because their MIC values for all the isolates except Escherichia coli were greater. Less the MIC value is, more effective towards bacterial sample to inhibit. For each test sample, DMSO was used a control. Usnea ghattensis showed that MIC values were varying between 25 and $3.125 \mathrm{~g} / \mathrm{mL}$ (Madamombe and Afolayan 2003).

As lichen extracts of four districts have showed good antibacterial activity against the test bacterial isolates namely Staphylococcus aureus, Salmonella Typhi, Pseudomonas aeruginosa, Bacillus subtilis, Klebsiella spp and Shigella spp. Hence, it is concluded that lichens are a good medicinal plant which is also supported by Karagoz et al. (2009).

On the basis of this finding, the methanolic extract of edible lichen (Everniastrum nepalense) possess a good candidate in the search for a natural antimicrobial agent against infections or diseases caused by the test bacteria except E. coli. The extracts of lichens should be further analyzed to isolate the specific antibacterial properties in them. Clinical trials should be carried out to explore the potential of the extracts in the treatment of the infectious diseases.

\section{CONCLUSION}

This study revealed that the lichen extract showed highest inhibitory effect on Gram-positive bacteria such as Staphylococcus aureus, Bacillus subtilis and mild inhibitory effect against Gram-negative bacteria such as Pseudomonas aeruginosa, Salmonella Typhi, Shigella spp, Klebsiella spp comparatively. Gram-negative Escherichia coli showed resistance to the lichen extracts from all four districts viz, Bhojpur, Taplejung, Dhankuta and Pachthar.

Hence, lichens are much effective against Grampositive bacteria than that of Gram-negative bacteria. Therefore, it is assumed that lichens are ethnobotanically important which are still in use as medicinal as well as food commodities by local ethnic community and can be used for the treatment of various diseases. This study also revealed that lichens might be useful as an antimicrobial agent following further extensive investigation.

\section{ACKNOWLEDGEMENTS}

We would like to express my sincere gratitude to 
Department of Microbiology, Central Campus of Technology for providing laboratory facilities that are required for smooth and efficient passage of work required for the completion of the project.

\section{CONFLICT OF INTEREST}

The authors declare no conflict of interest.

\section{REFERENCES}

Ahmadijan V (1993). The Lichen Symbiosis. New York: John Wiley \& Sons.

Azaizeh H, Fulder S, Khalilk and Said O (2003). Ethnomedicinal knowledge of local Arab practicioners in the Middle East Region. Fitoterapia 74: 98-108.

Basile A, Sorbo S, Giordano S, Ricciardi L, Ferrara S, Montesano D, Cobianchi RC, Vuotto ML and Ferrara L (2000). Antibacterial and allelopathic activity of extract from Castanea sativa leaves. Fitoterapia 71: 110-116.

Basri DF and Nor NHM (2014). Phytoconstituent Screening and Antibacterial Activity of the Leaf Extracts from Canarium odontophyllum Miq. American Journal of Plant Sciences 5: 2878-2886.

Behera BC, Verma N, Sonone A and Makhija U (2005). Antioxidantand antibacterial activities of lichen Usnea ghattensis in-vitro. Biotechnology Letters 27(14): 991-995.

Crawford SD (2015). Lichens used in traditional medicine. In: Rankovie B, editor. Lichen secondary metabolites. Switzerland: Springer International Publishing: 27-80.

Crockett M, Kageyama S, Homen D, Lewis C, Osborn $J$ and Sander L (2003). Antimicrobial properties of four Pacific Northwest lichens. Oregon State University Press, Coruallis 386.

Denton GH and Karlen W (1973). Lichenometry: its application to Holocene moraine studies in Southern Alaska and Swedish Lapland. Arctic and Alpine Research 5: 47-372.

Dulger B, Gucin F and Aslan A (1998). Cetraria islandica (L) Ach. Likenin Antimikrobial . Tr J. Biol 22: 111118.

Fiedler P, Gambaro V, Garbarino JA and Quihot W (1986). Epiphorellic acids 1 and 2, two diaryl ethers from the lichen Cornicularia epiphorella. Phytochemistry 25: 461-465.

Hegnauer R (1962). Chemotaxonomie der Pflanzen; eine Dbersicht iiber die Verbreitung und die Systematische Bedeutung der Pflanzenstoffe. Birkhauser, Basel.

Ingolfsdottir K (2002). Usnic acid. Phytochemistry 61: 729-736.

Jasuja ND, Sharma SK, Saxena R, Choudhary J, Sharma R and Joshi SC (2013). Antibacterial, antioxidant and phytochemical investigation of Thuja orientalis leaves. Journal of Medicinal Plants Research 7(25): 1886-1893.

Jezierski A, Bylinska E, and Seaward MRD (1999). Electron paramagnetic resonance (EPR) investigations of lichens -1: effects of air pollution. Atmospheric Environment 33(28): 4629-4635.

Karagoz A, Dogruoz N, Zeybeck Z and Aslan A (2009). Antibacterial Activity of some lichen extract. Journal of Medicinal Plant Research 3(12): 1034-1039.

Karaman I, Sanin F, Gulluce M, Ogutcu H, Sengul M and Adiguzel A (2003). Antimicrobial activity of aqueous and methanol extracts of Juniperus oxycedrus L. Journal of Ethnopharmacology 85: 231-235.

Kosanic M, Seklic D, Markovic S and Rankovic B (2014). Evaluation of antioxidant, antimicrobial and anticancer properties of selected lichens from Serbia. Digest Journal of Nanomaterials and Biostructures 9(1): 273-287.

Kumar PV, Chauhan SN, Padh H and Rajani M (2006). Search for antibacterial and antifungal agents from selected Indian medicinal plants. J. Ethnopharmacol. 107: 182-188

Lawrey JD (1986). Biological role of lichen substances. The Bryologist 89: 111-112.

Limbu DK and Rai BK (2012) Ethnomedicinal practices among the limbu community in Limbuwan Eastern Nepal. Glob J Hum Soc Sci H 8(2): 7-29.

Limbu RK (2013). Exploring indigenous knowledge system and Limbu cultural identity in Nepal. J Univ Grants Comm 2: 122-137.

Lodhia MH, Bhatt KR and Thaker US (2009). Antibacterial activity of essential oils from Palmarosa, Evening primerose, Lavender and Tuberose. Indian Journal of Pharmaceutical Sciences 71(2): 134-136.

Madamombe IT and Afolayan AJ (2003). Evaluation of antimicrobial activity of extracts from South African Usnea barbata. Pharmaceutical Biology 
41(3): 199-202.

Manojlovic NT, Vasiljevic P, Juskovic M, Najman S, Jankovic S and Milenkovic-Andjelkovic A (2010). HPLC analysis and cytotoxic potential of extracts from the lichen, Thamnolia vermicularisvar. subuliformis. Journal of Medicinal Plant Research 4 (9):817-823.

Manojlovic NT, Vasiljevic PJ and Markovic ZS (2010). Antimicrobial activity of extracts and various fractions of chloroform extract from the lichen Laurera benguelensis. Journal of Biological Research 13: $27-34$.

Nalubega R, Kabasa JD, Olila D and Kateregga J (2011). Evaluation of antibacterial activity of selected ethnomedicinal plants for poultry in Masaka district, Uganda. Research Journal of Pharmacology 5(2):18-21.

Ogbonnia SO, Enwuru NV, Onyemenem EU, Oyedele GA and Enwuru CA (2008). Phytochemical evaluation and antibacterial profile of Treculia africana Decne bark extract on gastrointestinal bacterial pathogens. Afr. J. Biotechnol. 7: 13851389.

Perry NB, Benn MH, Brennan NJ, Burgess EJ, Ellis G. Galloway D J, Lorimer SD and Tangney S (1999). Antimicrobial, antiviral and cytotoxic activity of New Zeland lichens. Lichenologist 31: 627-636.

Rowe JG, Saenz MT and Garcia MD (1989). Contribution a a'letudedel' activiteantibacterienne de queques lichens du suddel'Espagne. Pharmaceutical Francaise 47:89-94.

Rudrappa T and Bais HP (2008). Curcumin, a known phenolic from Curcuma longa, attenuates the virulence of Pseudomonas aeruginosa PA01 in whole plant and animal pathogenicity models. JAgric Food Chem 56: 1955-1962.

Sakha H, Hora R, Shrestha S, Acharya S, Dhakal D, Thapaliya S and Prajapati K (2018). Antimicrobial Activity of Ethanolic Extract of Medicinal Plants against Human Pathogenic Bacteria. TUJM 5(1): $1-6$

Shah NC (2014). Lichens of commercial importance in India. Scitech J. 1:32-36.

Shukla V, Joshu GP and Rawat MSM (2010). Lichens as a potential natural source of bioactive compounds. Phytochemistry Review 9: 303-314.

Srivastava P, Upreti DK, Dhole TN, Srivastava AK and Nayak MT (2013). Antimicrobial Property of Extracts of Indian Lichen against Human Pathogenic Bacteria, Interdisciplinary Perspectives on Infectious Diseases Volume 2013, Article ID 709348, 6 pages http://dx.doi. org/10.1155/2013/709348

Thapa B, Singh A and Tuladhar R (2018). In vitro Antibacterial effect of medicinal plants against multidrug resistant Gram negative bacteria. TUJM 5(1): 25-31

Toma N, Ghetea L, Nitu R and Corol DI (2001) Progress and perspectives in the biotechnology of lichens. Romanian Biotechnological Letters 6:1-15.

Yang Y and Anderson EJ (1999). Antimicrobial activity of a porcine myeloperoxidase against plant pathogenic bacteria and fungi. Journal of Applied Microbiology 86 (2): 211-220. 